\title{
SOME ASPECTS OF THE LAW OF GRATUITOUS PROMISES IN ILLINOIS
}

\section{I}

Liability upon a simple promise not under seal is predicated on the requirement of consideration," currently defined as a promise or an act "bargained for and given in exchange for the promise." While this narrow definition of a promissory obligation has at times been the subject of mild criticism ${ }^{3}$ and even the occasion of sportive comment, ${ }^{4}$ the literature in general has been chiefly concerned with the refinement of this bargain element contemplated by the doctrine of consideration..$^{5}$ Recently, however, writers have begun to question the very doctrine itself, and to advocate vigorously the abolition of consideration as the exclusive test of liability upon a promise. ${ }^{6}$

Some promises, of course, have been enforced even though no true consideration was given therefor. For instance, courts have upheld a promise to pay a debt barred by the statute of limitation, or discharged in bankruptcy, or unenforceable because of infancy; and have resorted to highly questionable constructions to obviate the rigorous requirements of the consideration doctrine. ${ }^{7}$ But while fictions may have succeeded in keeping the doctrine intact, a more realistic view recognizes such promises to be enforceable without consideration. ${ }^{8}$

In recent years attention has been called to the fact that courts have been enforcing gratuitous promises ${ }^{9}$ under such legal rubrics as fraud, waiver, and estoppel. None of these categories can be employed without doing some violence to their traditional meaning. Moreover, such gratuitous promises, disguised as they were under fictions, have been confined to isolated situations, with almost no cross-reference between them. The general underlying rule has

× Distinguish the "window dressing" obligations, where a promise is enforceable without consideration because it operates as a fraud upon a third party. See 5 Univ. Chi. L. Rev. 296 ( $\left.\mathrm{r}_{93} 8\right)$.

2 Rest., Contracts $\$ 75$ (I932).

3 Salmond, Jurisprudence 374 et seq. (7th ed. 1924$)$; Markby, Elements of Law $\$ 637$ (4th ed. 1889 ).

4 See Jessel, M. R. in Couldery v. Bartum, L.R. Ch. D. 394, 399 (I880).

5 Langdell, Mutual Promises as a Consideration for Each Other, 44 Harv. L. Rev. 496 (Igor); Williston, Mutual Assent in the Formation of Contracts, $x_{4}$ Ill. L. Rev. 85 (Igrg).

${ }^{\circ}$ Ballantine, Is the Doctrine of Consideration Senseless and Illogical, II Mich. L. Rev. 423 (Igr3); Arterburn, Liability for Breach of Gratuitous Promises, 22 Ill. L. Rev. I6I (I927); Wright, Ought the Doctrine of Consideration to Be Abolished from the Common Law, 49 Harv. L. Rev. I225 (I936); Shattuck, Gratuitous Promises-A New Writ, 35 Mich. L. Rev. 908 (I937).

7 See I Williston, Contracts c. vii (rev. ed. r936).

8 Ibid. On the relation of letters of credit to consideration see Thayer, Irrevocable Credits in International Commerce: Their Legal Effects, 37 Col. L. Rev. $\times 326$ (I937). On the seal and consideration see I Williston, op. cit. supra note 7 , at §§ 2x 7 -2xgA.

9 Note 6 supra. See also Sharp, Notes on Contract Problems and Comparative Law, 3 Univ. Chi. L. Rev. 277 (1936). 
been formulated by the Restatement in the following terms: "A promise which the promisor should reasonably expect to induce action or forebearance of a definite and substantial character on the part of the promisee and which does induce such action or forebearance is binding if injustice can be avoided only by enforcement of the promise." ro

As a preliminary matter, it should be noted that under Section go courts will not be called upon to enforce all gratuitous promises upon which the promisee has reasonably relied to his detriment. There will still remain the task of distinguishing and excluding from the operation of the stated rule social engagements or friendly accommodations. ${ }^{\text {II }}$ The difficulty may be all the more acute since gratuitous promises will normally occur among friends, neighbors, business associates and members of the family. This consideration, however, should merely serve as a caveat in the application of Section go.

With the promise as the source of the obligation, pertinent inquiry turns to the extent of the liability. It is arguable that since liability is predicated upon a promise, the measure of damages should be determined by the expectation interest as in the ordinary contract cases. ${ }^{\mathrm{Iz}}$ On the other hand, it has been suggested that the extent of damages should be determined by the actual losses sustained by the promisee in reliance upon the promise. ${ }^{\mathrm{I3}}$ It would seem preferable, however, not to set up any fixed rule, but rather to permit the courts to fix damages as the exigencies of the particular case demand. ${ }^{14} \mathrm{~A}$ detailed analysis of the cases so indicates.

\section{II}

The charitable subscription cases are clear examples of the legal enforcement of a gratuitous promise. ${ }^{15}$ In Beatty $v$. Western College ${ }^{x 6}$ the court held that

so Rest., Contracts $\$ 90$ (1932).

II "It would be exceedingly hurtful to the freedom of social intercourse to create even a suspicion in the public mind that those kind offers of advice and assistance, which take place among friends and kindred, could be converted into contracts which the law would enforce." Richards v. Richards, 46 Pa. St. 78,82 (I863). See also r Goble, Cases and Materials on Contracts 397 (1937).

${ }^{23}$ See on this point, Fuller and Purdue, The Reliance Interest in Contract Damages, 46 Yale L. J. 52, 63 et seq. ( 1936 ).

The term "promissory estoppel" tends to permit recovery of contract damages. Spelled out the term implies that under certain circumstances the promisor will be estopped from asserting lack of consideration. Promissory estoppel under this form is a substitute for consideration and leads easily to a uniform rule of contract damages. The words "gratuitous promise" give a neutral effect and might, therefore, be preferable.

${ }^{23}$ Gardner, An Inquiry into the Principles of the Law of Contracts, 46 Harv. L. Rev. r, 22 et.seq. (1932). See also Cohen, The Basis of Contract, 46 Harv.L. Rev. 553,578 el seq. (x933).

${ }^{24}$ See Fuller and Purdue, op. cit. supra note $\mathrm{I2}$, at $40 \mathrm{Or}$ et seq.

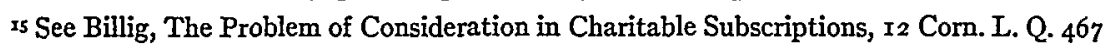
(1927); Humble, Promissory Estoppel in the Law of Contracts, 63 Am. L. Rev. 33 (1929). On the Ilinois cases, see, Murtaugh, Charitable Subscriptions in Illinois, 4 Univ. Chi. L. Rev. $43^{\circ}$ (1937).

${ }^{26}{ }_{177}$ Ill. 280, 52 N.E. 432 (I898). The courts have generally predicated recovery on the theory of detrimental reliance: Pryor v. Cain, 25 Ill. 263 (186r); Griswold v. Board of 
the donor was legally bound by his promise when expenditures had been made in reliance upon such promise. But, in Pratt v. Trustees of the Baptist Society of Elgin ${ }^{17}$ where no liabilities had been incurred, the court held that the subscription was a mere offer and was automatically revoked by the death of the subscriber. In an early case recovery was allowed on the ground that the labor in obtaining other subscriptions was sufficient consideration for the promise..$^{.8}$ Since such labor would generally be present in all subscription drives the requirement of injurious reliance would become superfluous. But, on the authority of the Pratt case, this approach has been rejected.99 On similar grounds the court repudiated the theory that the subscription of others may constitute consideration. ${ }^{20}$ The Appellate Court in In re Wheeler's Estate, ${ }^{2 \mathrm{x}}$ however, fictionally treated as a bargain transaction what would normally be considered a gift. The court indicated that the promise, by the charity, to apply the funds properly was sufficient consideration for the subscriber's promise. ${ }^{22}$ While reference to consideration in the charitable subscription cases has been criticized, their persistent appearance indicates the courts' determination to protect the reasonable expectations of charitable institutions. ${ }^{23}$ Whether or not the Supreme Court will follow the Wheeler or the Pratt case cannot be determined with any certainty. Perhaps a statute may be necessary to make at least a charitable subscription binding even though no reliance had been suffered upon it.24

In the light of section 90 requiring substantial action or forebearance to recover on the promise, it is interesting to note that in Trustees of M.E. Church of Illiopolis v. Garvey, ${ }^{25}$ the court permitted recovery even though the charity had, on the faith of the subscription, merely borrowed money to pay a pre-

Trustees of Peoria University, 26 Ill. 4x (r86r); Trustees of M. E. Church of Tlliopolis v. Garvey, 53 Ill. 40r (1870); Richelieu Hotel v. International Military Encampment Co., $\mathrm{r}_{40}$ IIl. 248,29 N.E. I044 (I892); Old Presbyterian Church v. The Estate of James Paxton, I80 IIl. App. 658 (Igr3).

${ }^{17} 93$ Ill. 475 (1879). Accord: Beach v. First M. E. Church, 96 Ill. I77 (I880) (offer revoked by insanity).

${ }^{88}$ See Kentucky Baptist Education Society v. Carter, 72 III. 247 (I874).

I9 Augustine v. Trustees of M. E. Society, 79 Ill. App. 452 (1898).

${ }^{20}$ See Cutwright v. Preachers' Aid Society, 27I 711 . App. I68, I7I (I933). In Trustees of M. E. Church v. Garvey, 53 Ill. 401,403 (1870) the court had reserved decision on this question.

${ }^{2 x}{ }_{28}$ Ill. App. I32, I N.E. (2d) 425 (1936). See also Allegheny College v. Nat. Chautauqua Bank, 246 N.Y. $3^{69}$, 559 N.E. 173 (1927).

22 For criticism of the consideration theory in the charitable subscription cases see I Williston, op. cit. supre note 7 , at $\S \mathrm{II} 6$.

${ }^{23}$ See Continental Illinois National Bank \& Trust Co. v. Harris, 359 Ill. 86, I94 N.E. 250 (1935).

${ }^{24}$ For form of such a statute see Billig, op. cit. supra note ${ }_{5} 5$, at 480 .

${ }^{25} 53$ III. 4 or (1870). 
existing debt. The decision of this case is somewhat fortified by the fact that, besides occasional dicta, ${ }^{26}$ the Illinois courts have not inquired into the extent of a charity's reliance. This is probably sound, particularly since the income from subscriptions may frequently be used not for purposes of expansion but to meet current liabilities and expenses. It is suggested, therefore, that Section go should accordingly be modified so far as charitable subscriptions are concerned. ${ }^{27}$

The enforcement of promises without consideration invites examination of the extent of liability in cases of gratuitous bailments and agencies. Thus it is clear that a gratuitous bailee, though not obligated to undertake the bailment, is liable in tort for gross negligence regarding the goods of which possession had been taken. ${ }^{28}$ Moreover, there are indications that in Illinois a surrender of possession would be sufficient to create liability against a gratuitous bailee on a promise wholly collateral to the bailment.29 The Court of Appeals of New York has definitely committed itself to such a view in Siegel v. Spear \& $\mathrm{Co}_{0}{ }^{30}$ where a gratuitous bailee was held liable on his promise to insure the goods of which he had taken possession. However, since courts have chosen to speak in terms of consideration, ${ }^{3 \mathrm{a}} \mathrm{a}$ bare promise unaccompanied by surrender of possession will not be enforced, even though the promisee has suffered a pecuniary loss on the strength of the promise. ${ }^{32}$

Similarly, as to the gratuitous agent, the Illinois court has said that once having initiated performance he has the obligations of any other agent. ${ }^{33}$ Thus he must inform the principal of any relevant information obtained in the course of his agency, ${ }^{34}$ and cannot use such information for his own benefit or to the detriment of the principal's interest. ${ }^{35}$ And it was held in Evan L. Reed Mfg.

${ }^{26}$ See Pryor v. Cain, 25 Tll. 263, 265 (I86r); Miller v. Ballard, 46 Il. 377, 380 ( 1868 ). These cases suggest that the measure of recovery should be determined by the amount of reliance.

27 As to pre-incorporation stock subscriptions see: I Williston, op. cit. supra note 7 , at § II8; Stevens, Corporations $\S \S 83,84$ (I936); Uniform Business Corporations Act, $\S 6$; 71 . Bus. Corp. Act $1933, \S 16$, IIl. Rev. Stat. I937, c. $32, \S$ I57.I6.

${ }^{28}$ Gray v. Merriam, $148 \mathrm{Ml}$. 179,35 N.E. 8ro (1893). For view that liability of bailee is in tort see: Winfield, The Province of the Law of Tort, c. v. (r93I); Anson, Principles of the Law of Contract $\S$ I33 (5th Am. ed. I930); cf. Beale, Gratuitous Undertakings, 5 Harv. L. Rev. 222 ( $18 \mathrm{gr}$ ) (liability is sui generis).

${ }^{29}$ See Whitesides v. Cook, $20 \mathrm{IIl}$. App. 574 (1886).

${ }^{30} 234$ N.Y. 479 , I38 N.E. 4 r4 (r923). For a discussion of analogous cases see, Arterburn, op. cit. supra note 6 .

${ }^{3 x}$ On this point see 32 Yale L. J. 609 (1923); 23 Col. L. Rev. 573 (I923); I Williston, $0 p$. cii. supra note 7 , at $\$ 138$.

${ }^{32}$ This result is also based on a distinction between misfeasance and non-feasance. See generally Story, Bailments $\$ \S$ I64-I7Id (8th ed. I87o). For a contrary view see Jones, Bailments 55 el seq. (4th ed. 1833).

33 Casey v. Casey, I4 Ill. II2 (I852); Dennis v. McCagg, 32 Ill. 429, 444 (I863). His liability, however, is limited to gross negligence. Hindman v. Borders, 89 III. $33^{6}$ (1878).

34 Rest., Agency \& 38 I (I933).

35 Id., at $\$ 387$. 
Co. v. Wurts ${ }^{6}$ that a gratuitous agent, who by his negligence had procured a defective insurance policy, was liable to the principal for the resulting loss. Although authorities agree that if the agent had not entered upon performance he would not be liable, ${ }^{37}$ on principle it is difficult to distinguish between a failure to obtain a valid policy and not getting one at all. ${ }^{8}$ Thus, in either case the agent should be liable if there has been justifiable reliance on the agent's promise and the principal has suffered a detriment. The Restatement of Agency, following Section 90 of the Restatement of Contracts provides that a gratuitous agent is liable in both situations, unless he has informed the principal, prior to a change in position, that he will not perform. ${ }^{39}$

Under certain circumstances courts of equity have granted specific relief upon a promise to make a gift of land..$^{0}$ It has been said that the promisee's assumption of possession and his making of valuable improvements constitute consideration for the promise. ${ }^{4 \mathrm{~T}}$ But it would seem that a bargain relationship was not contemplated by the parties. ${ }^{42}$ The proof of the promise to make the gift must be clear and unequivocal.43 This is especially necessary where the parties are closely related, since in such a case a mere accommodation might easily be taken for a promise. ${ }^{44}$

${ }^{36}$ I8 7 Ill. App. 378 (IgI4); Shapiro v. Amalgamated Trust \& Savings Bank, 283 Ill. App. 243 (1935) (whether agent was to be reimbursed for its services is not mentioned). Accord: Barile v. Wright, 256 N.Y. $x$, 175 N.E. 351 ( 1931 ).

37 Thorne v. Deas, 4 Johns. (N.Y.) 84 (I809); Comfort v. McCorkle, I49 Misc. 826, 268 N.Y. Supp. Ig2 (I933); I Mechem, Agency $\$$ x258 (2d ed. I914); 2 Joyce, The Law of Insurance $\$ 680$ (2d ed. $\mathrm{x} 9 \mathrm{I} 7$ ).

${ }^{38}$ The difficulty becomes all the more evident when the principal gave the gratuitous agent money to pay for policy. By analogy the agent should be liable.

39 "One who, by a gratuitous promise or other conduct which he should realize will cause another reasonably to rely upon the performance of definite acts of service by him as the other's agent, causes the other to refrain from having such acts done by other available means is subject to a duty to use care to perform such services or, while other means are available, to give notice that he will not perform." Rest., Agency $\$ 378$ (r933); see also § 4 or.

$4^{\circ 0}$ See McClintock, Equity $\$ 57$ (I936).

${ }_{48}$ "A court of equity will always enforce a promise upon which reliance is placed, and which induces the expenditure of labor and money in the improvement of land. Such a promise rests upon a valuable consideration. The promisee acts upon the faith of the promise. We can perceive no important distinction between such a promise and a sale." Kurtz v. Hibner, 55 Ill. $514,521$ ( 1870$)$.

42 Pound, Consideration in Equity, $x_{3}$ Ill. L. Rev. 667, 67 I et seq. (Igrg).

43 See Geer v. Goudy, r74 Ill. 5I4, 52x, 5I N.E. 623,625 (I898); Langston v. Bates, 84 Ill. 524,525 (1877).

44 In Burgess v. Burgess, 306 III. I9, 2I, I37 N.E. 403, 404 (I922), the court said that "where the contract is by a father to convey land to a child, the evidence is to be considered in view of the relation between the parties, which might indicate possession either under a contract or permissively as a benefit to the child."

Generally, the gift cases involve oral promises; but the rule of part performance is sufficient to take the case out of the Statute of Frauds. 
In regard to the extent of detrimental reliance necessary to obtain specific performance the courts have generally indicated that such relief will be granted to prevent fraud upon or injustice against the promisee.45 Despite this general language courts seldom inquire into the value of the permanent improvements made upon the land. In Clancy v. Flusky ${ }^{46}$ specific relief was granted even though the improvements were slight. However, where the promise of the gift was in return for services to be performed, specific relief is usually granted only where the statute of limitations has run and the value of the services approximated the value of the land.47 The distinction is perhaps questionable, especially since, under certain circumstances, the court granted only quasicontractual relief even though permanent improvements had been made..$^{8}$

Finally, a consideration of the license cases is relevant. It is generally accepted that the mere fact that consideration is paid for a license does not make it irrevocable. ${ }^{49}$ Moreover, as to cases where a gratuitous licensee, to avail himself of the license, has substantially changed his position, the courts have shown no unanimity of treatment. A minority of courts have contended that the license is translated into an easement..$^{\circ}$ But the majority, charging the licensee with knowledge of the law, have held that he cannot claim to have been misled to his detriment. ${ }^{5 x}$ It has been suggested, however, that where permission is given to use the land of another in some particular way, it becomes a matter of construction as to the character of the interest purported to be created. On the basis of this suggestion, it is said that the courts part company in the construction of a mere "permission" to use the land of an-

${ }_{45}$ Stephens v. Collison, 3 I3 Ill. 365, 375, I45 N.E. 8I, 85 (I924); McCalister v. McCalister, 342 Ill. 231, 236, 173 N.E. 745,747 (1930).

${ }_{46}^{4}$ I87 Ill. 605,58 N.E. 594 (I900).

${ }_{47}$ Willis v. Zorger, 258 III. 575 , ror N.E. 963 (x913); Warren v. Warren, ro5 IIll. 568 (1883); Aldrich v. Aldrich, 287 Ill. 2I3, I22 N.E. 472 (I9I9); Weir v. Weir, 287 Ill. 495 , I22 N.E. 868 (1919); Edwards v. Brown, 308 Ill. 350, I39 N.E. 618 (I923); Holsz v. Stephen, 362 Ill. 527, 200 N.E. 6or (1936) (probably distinguishable on fact that it involved a promise to bequeath in return for services).

${ }^{8}{ }^{8}$ Thus in Worth v. Worth, 84 Ill. 442 ( 1877 ) where the promise to convey could not be clearly established the court permitted recovery for the valuable improvements minus the rental value of the land. In Ranson v. Ranson, 233 Ill. 369,84 N.E. 210 (1908) the court, under similar circumstances, allowed an equitable lien upon the premises to the extent of the permanent improvements. It is arguable that where permanent improvements have been made specific performance should not be uniformly granted, even though the promise to convey is clearly proved.

492 Tiffany, Real Property I206 (I920).

so See Shattuck, Gratuitous Promises-A New Writ, 35 Mich. L. Rev. 908, 924 et seq. (1937).

${ }_{s x}$ See $x$ Williston, op. cit. supra, note 7 at $\$$ r39; Clark, Licenses in Real Property Law, 2 I Col. L. Rev. 757, 779 et seq. (I92I); Hohfeld, Faulty Analysis in Easement and License Cases, 27 Yale L. J. 66, 92 et seq. (I917). 
other..$^{2}$ Courts, however, have not specifically followed this suggested analysis. ${ }^{53}$

The Illinois decisions are not in harmony. In Woodward v. Seely, ${ }^{54}$ a case of first impression, the court denied specific relief to a gratuitous licensee who had built a mill in reliance upon the licensor's permission to flood the latter's land. In Russell v. Hubbard, ${ }^{55}$ however, a license was held irrevocable where the licensee attached his building to the adjacent wall of the licensor. The Russell case has been subsequently limited to its facts; ${ }^{66}$ and the rule established by Woodward v. Seely has been generally followed. ${ }^{57}$

Occasionally the Illinois court has indicated that equity will interfere to prevent the revocation of a license in situations involving fraud or undue hardship $;{ }^{58}$ but the extent to which relief will be given was not specified. In Girard v. The Lehigh Stone Co., ${ }^{59}$ the court seemed to open a compromise between the two extreme positions generally taken in the license situations. In that case, the agreement was construed as a license to discharge water across the licensor's land. The court indicated that the licensor had no standing in equity unless he reimbursed the licensee for his expenditures, and hence refused to enjoin the latter's acts. It is suggested that this is a far more reasonable way of adjusting the difficulties. ${ }^{60}$ It will, on the one hand, adequately protect a person who must make large expenditures to avail himself of the license; and on the other hand avoid the manifest injustice of converting a neighborly act into a grant of a permanent interest in the land.6x

In conclusion the suggestion to be found in the cases that the measure of damages should sometimes be determined by the reliance interest may open

${ }^{52} 2$ Tiffany, Real Property I208 et seq. (I920). Since these "licenses" are generally given by oral declaration the court has at times argued that to make it irrevocable is to create an interest in land by parol in contravention of the Statute of Frauds. Tanner v. Volentine, 75 Ill. 624 (I874); City of Kewanee v. Otley, 204 Ill. 402,68 N.E. 388 (I903). Obviously this argument is unsound for even a fee may be created by parol in the gift cases.

53 However, in St. Louis National Stock Yards v. The Wiggins Ferry Co., 102 Ill. 514 (I882) it was specifically argued that the transaction did not contemplate a license. See also Boland v. Walters, 346 Ill. I84, $x 78$, N.E. 359 ( $193 \mathrm{r}$ ) (court indicated that the circumstances tended to show a license).

54 II III. 157 ( 1849 ).

5559 IIll. 335 ( 187 I).

${ }^{56}$ Kamphouse v. Gaffiner, 73 Ill. 453,461 (I874).

57 The St. Louis National Stock Yards v. The Wiggins Ferry Co., II 2 Ill. 384 (I885); Simpson v. Wright, 21 Ill. App. 67 (I886); Murray v. Gibson, 2I Ill. App. 488 (I886); Morse v. Lorenz, 262 Ill. II5, I04 N.E. 237 (IgI4). In Entwhistle.v. Henke, 2 II Ill. 273, 277, 7 I N.E. 990, 99I (1904) the court said: "If the rule is harsh and unjust in its operation, the remedy must now be afforded by enactments of the law-making body of the State." But see note 59 infra.

$5^{8}$ See Baird v. Westberg, 34 I Ill. 616, 6I8, I73 N.E. 820, 82I (r930).

${ }^{59} 280$ III. 479 , II7 N.E. 698 (I9I7).

${ }^{60}$ See Shattuck, op. cit. supra note 50. ${ }^{65}$ See Clark, op. cit. silpra note 5I, at $78 \mathrm{I}$. 
the way for adjusting the difficulties following the revocation of a unilateral contract after the promisee has partly performed to his detriment..$^{62}$ Further a frank recognition of the fact that promises may be enforced without consideration might lead to further modifications of the bargain theory of consideration. ${ }^{6}$

\section{THE ECONOMIC REGULATION OF AIR TRANSPORT}

Government regulation of private agencies of transportation has become a part of our national life. Fifty years ago, the first Act to Regulate Commerce ${ }^{x}$ created the Interstate Commerce Commission, which began to regulate the railroads; more recently the jurisdiction of the Commission has been extended to motor carriers; ${ }^{2}$ and now Congress is facing the problem of regulating air transportation. ${ }^{3}$

Barely fifteen years old air transport has grown from an experiment to an industry of national scope. Remarkable technical advance has changed flying from a fool-hardy adventure 4 to a commonplace experience, and with the change has come a tremendous increase in the volume of air traffic.5 But despite this growth the financial condition of the domestic airlines has steadily declined. ${ }^{6}$ Especially since the enactment of the present Air Mail Law have losses been heavy. In I936 the loss totaled \$9Io,000, and in I937 it is estimated at $\$ 3,000,000 .^{7}$ It has been said that of the I20 millions of private capital invested in the air transport industry, more than 60 millions have been lost. ${ }^{8}$

${ }^{62}$ See Fuller and Purdue, op. cit. supra, note I2, at $4 \mathrm{IO}$ et seq.

${ }^{6} 3$ See Report of New York Law Revision Commission 9I et seq. (1936).

I 24 Stat. 379 ( 1887 ), and amendments; 49 U.S.C.A. \$\$ 1-40 (Supp. r937).

$=$ Motor Carrier Act of 1935, 49 Stat. 543 (1935), 49 U.S.C.A. § 3 or (Supp. 1937).

3 For the legislation at present before Congress, see note $6 \mathrm{r}$ infra.

4 With the expansion of flying, both commercial and private, it became apparent as early as 1922 that some kind of governmental regulation was necessary to safeguard the public. Although several progressive states did enact licensing laws and some traffic regulations, they were not very effective, as state lines mean nothing to an airplane.

Constitutional doubts over the power of the federal government to regulate into the air, which seemed quite serious at the time, never got beyond the halls of Congress. The Air Commerce Act, 44 Stat. 468 (1926), 49 U.S.C.A. \& 17 I (Supp. I937), was finally enacted under the commerce clause, on May 20, I926. The act confers upon the Department of Commerce jurisdiction over all civil flying, commercial and private. Created under this authority, the Bureau of Air Commerce promulgates rules for air traffic, safety, the licensing of pilots and equipment, and supervises the airways.

5 See Tables, Annual Report of the Postmaster General, 1936, 29.

${ }^{6}$ See Barney, The Aviation Industry, Appendix 66-67 (1937) for consolidated earnings statement of airlines.

7 See statement of Col. Gorrell, President, Air Transport Assoc. of America, reported in Hearings, Post Office Department, Appropriations Bill, r939, 536.

${ }^{8}$ Ibid. 